\title{
Lick rates in New Zealand white rabbits
}

\section{ROBERT W. SCHAEFFER}

Auburn University, Auburn, Ala. 36830

and

MIKE DAVID

Napa State Hospital, Napa, Calif. 94558

A technique for measuring lick rate in the rabbit is described. Using this technique, lick rates in male and female New Zealand white rabbits were found to be constant and independent of type of solution tested (water, $4 \%, 16 \%$, and $32 \%$ sucrose) and number of hours of deprivation $(12,24$, and $48 \mathrm{~h})$. These data corroborate data previously reported regarding constancy of the licking reflex in other mammals.

In the course of attempting to measure the rate of the licking reflex in the rabbit, a number of difficulties in recording and instrumenting the licking response in this animal were encountered. These difficulties were associated with the topographically different types of behaviors the rabbit uses to accomplish fluid ingestion. Visual observation indicated that although the rabbit ingests the larger part of its daily fluid intake by immersing its mouth in the fluid and sucking up the fluid, some fluid ingestion and all grooming behavior are accomplished by lapping and/or licking behaviors. The technique we developed for measuring the rate of the licking response in the rabbit may be of value to other investigators who are interested either in describing the rate of the licking reflex or in programming licking as an instrumental response in organisms which, like the rabbit, use sucking behaviors and licking behaviors to ingest fluids.

An initial attempt to record the licking rate in the rabbit was made by using a standard contact drinkometer circuit, with one side of the circuit immersed (via a wire electrode) in an open plastic watering pan and the other side of the circuit attached to the cage floor. When presented with the water pan under this condition, all Ss persisted in making mouth and lip contacts with the surface of the water. Although the resulting continuous activation of the drinkometer provided a reliable measure of the total time the Ss spent drinking, these mouth-fluid and lip-fluid contacts obscured totally the occasional individual tongue-fluid contacts that were readily discernible visually.

Since our interest was in the rate of the licking response, rather than in total time spent drinking, we tried to eliminate the intrusion of these unwanted mouth and lip contacts with the surface of the fluid by providing the Ss with standard small-bore metal drinking tubes. These were the same small-bore metal drinking tubes that are commonly used for providing fluids to small laboratory animals, such as the rat. This method of fluid presentation also proved to be totally unacceptable. The Ss sucked, nuzzled, nibbled, and licked on the tube when it protruded inside the cage.
Further, the small aperture in the tube prevented the Ss from easily obtaining the relatively large quantities of fluid they require for their daily maintenance. When the tube was withdrawn to the outside of the cage, the nose-tube and mouth-tube contacts were eliminated, but the problem of Ss' obtaining adequate water for daily maintenance was exacerbated.

All laboratory caretakers know that open watering pans are not acceptable for daily provision of fluid for the rabbit. The rabbit invariably fouls an open water supply with excrement, bits of food, and pieces of litter, and good sanitary practices require frequent cleaning and changing of open water pans. Since we were interested in providing a sanitary water supply that would reduce caretaking activities, we had ordered a drinking device that was advertised as a virtually foolproof method of preventing laboratory animals from fouling their water supply. Basically, this water system consists of a large-bore stainless steel tube into which a ball bearing is inserted. Each contact with the tip of the drinking tube displaces the ball bearing and permits fluid to flow from the tube and from the bottle reservior. The amount of fluid that flows from the tube is regulated by an adjustment collar which regulates displacement of the ball bearing.

While testing the adequacy of this watering system for providing the daily fluid ratio for the rabbits, we noted that the Ss attempted to, but could not, suck from the end of the tube. Sucking responses drew the ball to the end of the tube, closed off the tube opening, and quickly and effectively discouraged these responses. We also noted that each contact the rabbit made with the tube produced an audible click. Visual inspection indicated that the click was associated with the movement of the ball bearing in the stainless steel tube. By systematically withdrawing the tube from the cage, we were able to induce the rabbit to sustain licking at the end of the tube and to observe that each lick produced a distinctive click of the ball bearing that was associated with displacement of the ball bearing. Using a voice-operated relay with a throat microphone taped to the bottle reservior, we adjusted the sensitivity of the voice-operated relay so that each click of the ball bearing activated the relay and provided an indicator of the rate of licking. The rabbit lick-rate data we present here were obtained by using this methodology.

\section{METHOD \\ Subjects}

Ss were two adult male and two adult female New Zealand white rabbits. Ss were approximately 18 months old when tested. Prior to the experiment, Ss were trained to drink from an Atco watering tube by removing their water dishes for periods of $24 \mathrm{~h}$. Purina rabbit food was available at all times except during the deprivation periods and sucrose test sessions, as described below.

\section{Apparatus}

Ss were housed individually in Hoeltge rabbit cages. Ss were maintained and tested in these cages throughout the experiment. 
Table 1

Mean Momentary Lick Rates and Overall Ranges for 1-Sec Measures and Bursts of 3 Sec or More*

\begin{tabular}{|c|c|c|c|c|c|c|c|c|c|}
\hline \multirow{4}{*}{$\frac{\mathrm{S}}{\text { Male }}$} & \multirow{4}{*}{$\begin{array}{c}\begin{array}{c}\text { Measure } \\
\text { (in } \\
\text { Sec) }\end{array} \\
1 \\
3\end{array}$} & \multicolumn{6}{|c|}{ Solution Tested } & \multirow{3}{*}{\multicolumn{2}{|c|}{$\begin{array}{c}\begin{array}{c}\text { Grand Mean } \\
\text { and Range }\end{array} \\
\text { All Conditions }\end{array}$}} \\
\hline & & \multicolumn{3}{|c|}{ Water } & \multicolumn{3}{|c|}{ Sucrose } & & \\
\hline & & 12 & 24 & 48 & 4 & 16 & 32 & & \\
\hline & & $\begin{array}{l}5.1 \\
4.6\end{array}$ & $\begin{array}{l}5.4 \\
5.4\end{array}$ & $\begin{array}{l}5.2 \\
5.2\end{array}$ & $\begin{array}{l}5.3 \\
5.3\end{array}$ & $\begin{array}{l}5.6 \\
5.5\end{array}$ & $\begin{array}{l}5.7 \\
5.3\end{array}$ & $\begin{array}{l}5.4 \\
5.2\end{array}$ & $\begin{array}{l}4.0-7.0 \\
4.5-5.8\end{array}$ \\
\hline Male & $\begin{array}{l}1 \\
3\end{array}$ & $\begin{array}{l}5.5 \\
5.6\end{array}$ & $\begin{array}{l}5.6 \\
5.5\end{array}$ & $\begin{array}{l}5.5 \\
5.3\end{array}$ & $\begin{array}{l}5.3 \\
5.3\end{array}$ & $\begin{array}{l}5.6 \\
5.6\end{array}$ & $\begin{array}{l}5.5 \\
--\end{array}$ & $\begin{array}{l}5.5 \\
5.4\end{array}$ & $\begin{array}{l}5.0-6.0 \\
5.0-6.0\end{array}$ \\
\hline Female & $\begin{array}{l}1 \\
3\end{array}$ & $\begin{array}{l}5.3 \\
5.4\end{array}$ & $\begin{array}{l}5.4 \\
5.1\end{array}$ & $\begin{array}{l}5.3 \\
5.5\end{array}$ & $\begin{array}{l}5.5 \\
--\end{array}$ & $\begin{array}{l}5.3 \\
--\end{array}$ & $\begin{array}{l}5.5 \\
--\end{array}$ & $\begin{array}{l}5.4 \\
5.3\end{array}$ & $\begin{array}{l}4.0-7.0 \\
4.9-5.9\end{array}$ \\
\hline Female & $\begin{array}{l}1 \\
3\end{array}$ & $\begin{array}{l}5.2 \\
--\end{array}$ & $\begin{array}{l}5.0 \\
--\end{array}$ & $\begin{array}{l}5.2 \\
5.1\end{array}$ & $\begin{array}{l}5.4 \\
5.6\end{array}$ & $\begin{array}{l}5.5 \\
5.4\end{array}$ & $\begin{array}{l}5.6 \\
--\end{array}$ & $\begin{array}{l}5.3 \\
5.5\end{array}$ & $\begin{array}{l}4.0-7.0 \\
5.0-6.0\end{array}$ \\
\hline
\end{tabular}

* Data for water in terms of hours of deprivation. All sucrose solutions are for 24-h deprivation. All empty cells indicate absence of lick bursts of at least 3-sec duration for $S$ on that test condition.

Atco ball watering tubes and a 1,000-cc Atco reservior were used. When $S$ licked the end of the Atco drinking tube, the ball bearing emitted an audible click. A Grason-Stadler voice-operated relay, Model $7300 \mathrm{~A}$, was used to record these clicks via a Grason-Stadler throat mike, Model $7300 \mathrm{M}$, that was taped to the water reservior. The sensitivity of the voice-operated relay was adjusted so that each click operated the relay. An Esterline-Angus digital event recorder, with paper speed set to $.5 \mathrm{in} . / \mathrm{sec}$, was used to record licks.

\section{Procedure}

Lick rates for water were obtained under 12, 24, and $48 \mathrm{~h}$ water deprivation. Lick rates for $4 \%, 16 \%$, and $32 \%$ sucrose solutions, by weight, were also obtained, under $24 \mathrm{~h}$ water deprivation. Immediately following each sucrose test session, the $\mathrm{Ss}$ were given ad lib water for $24 \mathrm{~h}$-then the next sucrose test was begun.

\section{RESULTS AND DISCUSSION}

Lick rates were analyzed, using the procedures described by Schaeffer \& Premack (1961) and Schaeffer $\&$ Huff (1965). The specific lick rates obtained were: (1) momentary lick rates, obtained from a second-by-second analysis of all recorded licks in a session, (2) mean lick rates obtained only from sustained bursts of licking that were of 3 or more seconds in duration, (3) changes in momentary rates within sustained bursts of licking of 3 or more seconds' duration, and (4) changes in momentary lick rates within sessions.

As Table 1 shows, the mean momentary lick rates for all Ss were highly consistent for all conditions. Maximum between-S variability for mean momentary lick rates was less than 1 lick/sec. Inspection of Table 1 shows that neither type of solution nor number of hours of deprivation bore any systematic relationship to mean momentary lick rates.

For all Ss on all trials, the initial lick measured in the first second of each session tended to be about 1 to 1.5 licks faster than the mean momentary lick rate for the session. The terminal lick rate measured in the last second of licking in a session was about .5 to 1 licks/sec slower than the mean momentary rate for the entire session. A slight within-burst decrement in lick rate in lick bursts of more than $3 \mathrm{sec}$ duration was noted, but was less well defined than the within-session decrement.
Approximately $98 \%$ of all recorded licks were made at a rate of either 5 or 6 licks/sec. Lick rates of $7 / \mathrm{sec}$ were observed only during the first second or two of the initial part of a session. Rates of $4 / \mathrm{sec}$ were observed only during the last second of a sustained lick burst in the last part of a session. Given a lick rate of $4 / \mathrm{sec}$, the probability that licking would terminate in $1 \mathrm{sec}$ was 1.00 .

With only five exceptions of Mode 6, the modal rate for all Ss on all trials was 5 licks/sec. Four of these exceptions were accounted for by the fact that all Ss abruptly stopped drinking the $16 \%$ and $32 \%$ sucrose solutions within a few seconds after these test trials were begun. Subsequent drink bursts intitated on the tube when it contained $16 \%$ and $32 \%$ sucrose solutions were of less than a second's duration. Thus the modal rates of 6 represent only elevated initial rates of licking and are not representative of the modal lick rate of 5 licks/sec found in sustained drinking bursts when Ss were drinking water or $4 \%$ sucrose. All Ss behaved as if the $16 \%$ and $32 \%$ sucrose solutions were aversive. However, when these solutions were immediately followed by water, all Ss engaged in sustained drinking as usual and their lick rates did not differ from those of other trials on which water and $4 \%$ sucrose were used as the test solutions.

The results of the present experiment, in addition to corroborating the constancy of lick reflex thus far identified in other mammals, under a variety of experimental conditions, offer an alternative methodology to the contact drinkometer circuit as a means of measuring lick rate. Why rabbits should find some sucrose solutions aversive, when most other mammals appear to prefer most sucrose solutions over water, is an experimental question that bears further investigation.

\section{REFERENCES}

Schaeffer, R. W., \& Premack, D. Licking rates in infant albino rats. Science, $1961,134,1980-1981$.

Schaeffer, R. W., \& Huff, C. Lick rates in cats. Psychonomic Science, $1965,3,377-378$.

(Received for publication April 16, 1973.) 